\title{
EKSTRAKSI ABU KAYU DENGAN PELARUT AIR MENGGUNAKAN SISTEM BERTAHAP BANYAK BERALIRAN SILANG
}

\author{
Imam Santosa dan Endah Sulistiawati
}

Program StudiTeknik Kimia Universitas Ahmad Dahlan

Kampus III UAD, Jl. Prof Soepomo, Janturan, Warungboto, Yogyakarta.

Telp. (0274)563515 ext. 3209

Email:imamsuad@yahoo.com

\begin{abstract}
As an agricultural country, Indonesia has natural resources are very abundant, one of which is wood. Wood ash from household and industrial waste has not been used, whereas according to Pitman high potassium content. The solubility of potassium carbonate in high water, so effective when extracted with water. However, high humidity in Indonesia drying wood for fuel so low that allegedly affect the quality of the ash obtained. In this research, the extraction of wood ashes with water using a solvent system gradually many wing cross .

The experimental study was conducted in a university laboratory Ahmad Dahlan, Yogyakarta. The procedure used is the extraction of wood ash 200 , 300 and 400 grams with $1000 \mathrm{ml}$ of solvent water for 5 minutes using a glass beaker, filtering with the aid of a vacuum pump, and acidi alkalimetri analysis using $0.1 \mathrm{~N} \mathrm{HCl}$ residual solids by filtration and then in water kontakkan again and so do the same thing 5 times . Raw materials derived from wood ash combustion for drying of the wood cutting industry and water used in the form aquadestilata .

Extract wood ash derived from the combustion for drying small normality sawmill industry. The results of the analysis can be made curve that describes the operating line and curve logarithmic form of the equation of equilibrium in the form of linear equations. Moreover, it can be made a graph illustrating a series of 5 stages of operation which is a combination of single phased extraction .
\end{abstract}

Keywords : Extraction, ash wood, cross flow.

\section{Pendahuluan}

Ekstraksi merupakan suatu proses pemisahan dimana komponen mengalami perpindahan massa dari suatu padatan ke cairan atau dari cairan ke cairan lain yang bertindak sebagai pelarut. Berbagai penelitian tentang ekstraksi padat-cair telah banyak dilakukan [1]. Ekstraksi padat cair, yang sering disebut leaching, adalah proses pemisahan zat yang dapat melarut (solut) dari suatu campurannya dengan padatan yang tidak dapat larut(innert) dengan menggunakan pelarut cair. Operasi ini sering dijumpai di dalam industrimetalurgi dan farmasi, misalnya pada pemisahan biji emas, tembaga dari biji-bijian logam, produk-produk farmasi dari akar atau daun tumbuhan tertentu.

Abu ialah mineral pembentuk abu yang tertinggal setelah lignin dan selulosa habis terbakar [2]. Abu yang tersisa dari proses pembakaran terdiri atasbahan-bahan anorganik pada kayu sedangkan bahan organiknya habis terbakar. Sjostrom [3] mengemukakan bahwa abu asalnya terutama dari berbagai garam yang diendapkan dalam dinding-dinding sel dan lumen. Endapan yang khas adalah berbagai garam-garam logam, seperti karbonat, silikat, oksalat, dan fosfat. Komponen logam yang paling banyak jumlahnya adalah kalsium diikuti kalium dan magnesium. Dalam proses pengabuan, bahan-bahanorganik yang terkandung dalam kayu akan terbakar sedangkan bahan-bahan anorganik akan tertinggal.

Ekstrak abu dibuat dengan mencampurkan abu limbah pertanian dengan air. Suspensi yang terjadi disaring. Untuk memperoleh konsentrasi yang tinggi cairan ekstrak abu yang diperoleh digunakan untuk mengektraksi abu baru. Abu tandan kosong sawit sebagai limbah pada pabrik CPO mengandung kalium sebagai kalium karbonat sebanyak 25,92\% berat [4]. Konsentrasi ekstrak abu untuk membuat serat dari daun nenas adalah 4,2 N [5]. Sulistiawati mengambil serat dari sabut kelapa menggunakan ekstrak abu dari 


\section{Chemica}

Volume 1, Nomor 1, Juni 2014, 33-39

ISSN : 2355-8776

kelopak batang pisang dengan konsentrasi alkali aktif 0,7180 gek/L [6]. Kadar kalium dari abu kulit kayu lunak 9,8\%, abu kayu lunak 12,4\%, abu kulit kayu keras 12,2\%, abu kayu keras 20,4\% [7].

Sebagai negara agraris Indonesia memiliki sumber daya alam yang sangat melimpah, salah satunya kayu. Abu kayu dari limbah rumah tangga maupun industri belum dimanfaatkan, padahal menurut Pitman kandungan kaliumnya lumayan tinggi. Kelarutan kalium karbonat dalam air cukup tinggi, sehingga cukup efektif jika diekstraksi dengan air. Namun kelembapan udara di Indonesia cukup tinggi sehingga pengeringan kayu untuk bakar diduga rendah yang berpengaruh pada kualitas abu yang diperoleh. Hal inilah yang dipelajari dalam penelitian ini.

\section{Landasan Teori}

Pada penelitian ini dilakukan ekstraksi abu kayu dengan pelarut air menggunakan sistem bertahap banyak beraliran silang. Proses dimulai dengan pencampuran umpan padatan dan pelarut dalam tahap pertama; kemudian padatan hasil saringan dari tahap ini dikontakkan dengan pelarut baru pada tahap berikutnya, dan demikian seterusnya.Larutan yang diperoleh ditampung secara terpisah dan dianalisis secara acidi-alkalimetri.

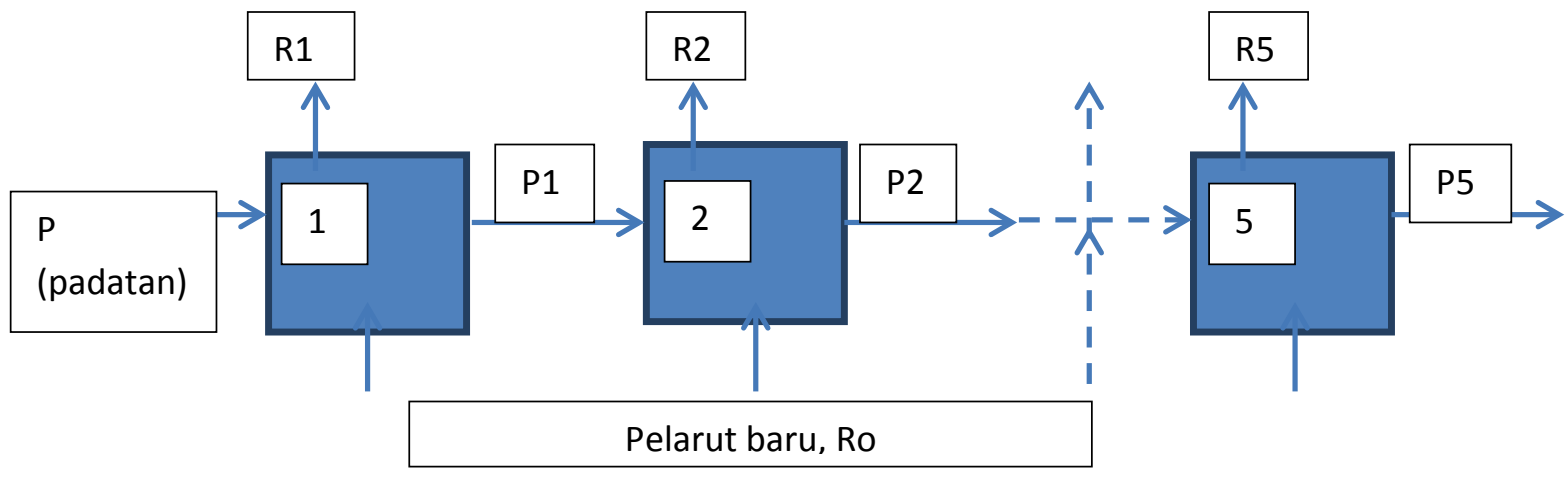

Gambar 1. Sistem bertahap banyak beraliran silang

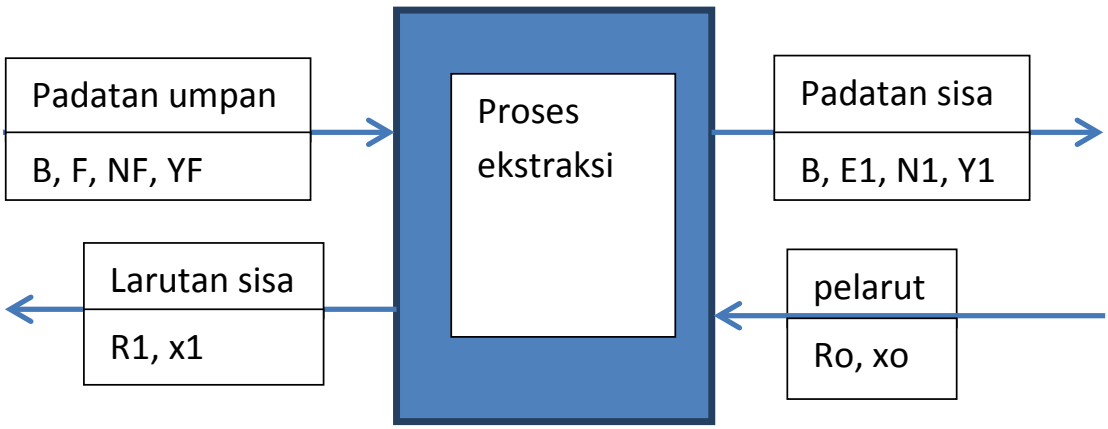

Gambar 2. Arus dan variabel yang terlibat dalam satu proses ekstraksi.

Dari model diatas dapat ditinjau neraca masa untuk tiap tahap.

Neraca massa pelarut

F. $(1-y F)+$ Ro.(1- xo ) = E1.(1-y1) + R1.(1-x1)

Neraca massa zat terlarut

$\mathrm{F} . \mathrm{yF}+\mathrm{Ro} . \mathrm{xo}=\mathrm{E} 1 . \mathrm{y} 1+\mathrm{R} 1 . \mathrm{x} 1$

Neraca massa innert

$\mathrm{B}=\mathrm{NF} . \mathrm{F}=\mathrm{E} 1 . \mathrm{N} 1$

Neraca untuk larutan $(\mathrm{A}+\mathrm{C})$

$\mathrm{F}+\mathrm{R} 0=\mathrm{E} 1+\mathrm{R} 1=\mathrm{M} 1$ 
Untuk menenpatkan titik M1 pada kurva ekstraksi maka nilai koordinatnya adalah :

$\mathrm{NM} 1=\mathrm{B} /(\mathrm{F}+\mathrm{Ro})=\mathrm{B} / \mathrm{M} 1$

$\mathrm{YM} 1=(\mathrm{F} . \mathrm{YF}+\mathrm{Ro} . \mathrm{Xo}) /(\mathrm{F}+\mathrm{Ro})$

Deskripsi secara grafik untuk sistem ekstraksi bertahap tunggal nampak pada gambar 3.

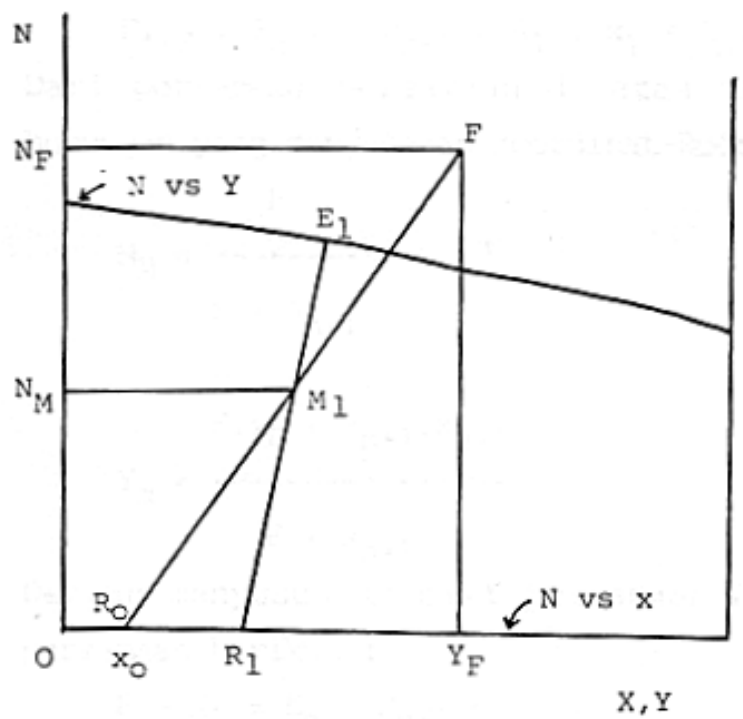

Gambar 3. Grafik ekstraksi untuk sistem bertahap tunggal

\section{Metodologi}

Penelitian dilakukan secara eksperimental di laboratorium universitas Ahmad Dahlan, Yogyakarta. Prosedur yang dipakai adalah ekstraksi abu kayu 200, 300 dan 400 gram dengan pelarut air 1000 ml selama 5 menit menggunakan gelas beaker, penyaringan dengan bantuan pompa vakum, dan analisis acidi alkalimetri menggunakan $\mathrm{HCl}$ 0,1 N. Padatan sisa penyaringan kemudian di kontakkan dengan air lagi dan seterusnya dilakukan hal yang sama sebanyak 5 kali. Bahan baku abu kayu diperoleh dari sisa pembakaranuntuk pengeringan dari industri pemotongan kayu dan air yang digunakan berupa aquadestilata.

Data yang diperoleh kemudian diolah sedemikian rupa sehinnga dapat dideskripsikan dalam bentuk grafik.

\section{Hasil dan Pembahasan}

\section{Perbandingan Ekstrak Terhadap Rafinat}

Dari penelitian diperoleh ekstrak alkali pada ekstraksi pertama untuk abu kayu 200, 300 dan 400 gram adalah 0,057, 0,0765 dan 0,132 N, jauh lebih rendah dibanding hasil penelitian sebelumnya yang mencapai 0,7180 gek/L [6,8]. Karena rendahnya kelarutan CaCO3 dalam air (0,002 gr/100 gr air) maka garam yang larut dalam air mayoritas berupa K2CO3 (125 gr/100 gr air) dengan berat molekul138,2 diperolehfraksi berat esktrak alkali terhadap berat abu rata-rata $9 \%$. Hal ini menunjukkan pembakaran kayu di industri pemotongan kayu untuk pengeringan belum terbakar sempurna, karena kadar kaliumnya tidak setinggi di literatur [8].

Kemudian dilakukan analisis perbandingan fraksi berat alkali di ekstrak terhadap rafinat dan perbandingan fraksi berat alkali di ekstrak terhadap prose sehingga diperoleh grafik sebagai berikut : 
Chemica

Volume 1, Nomor 1, Juni 2014, 33-39

ISSN : 2355-8776

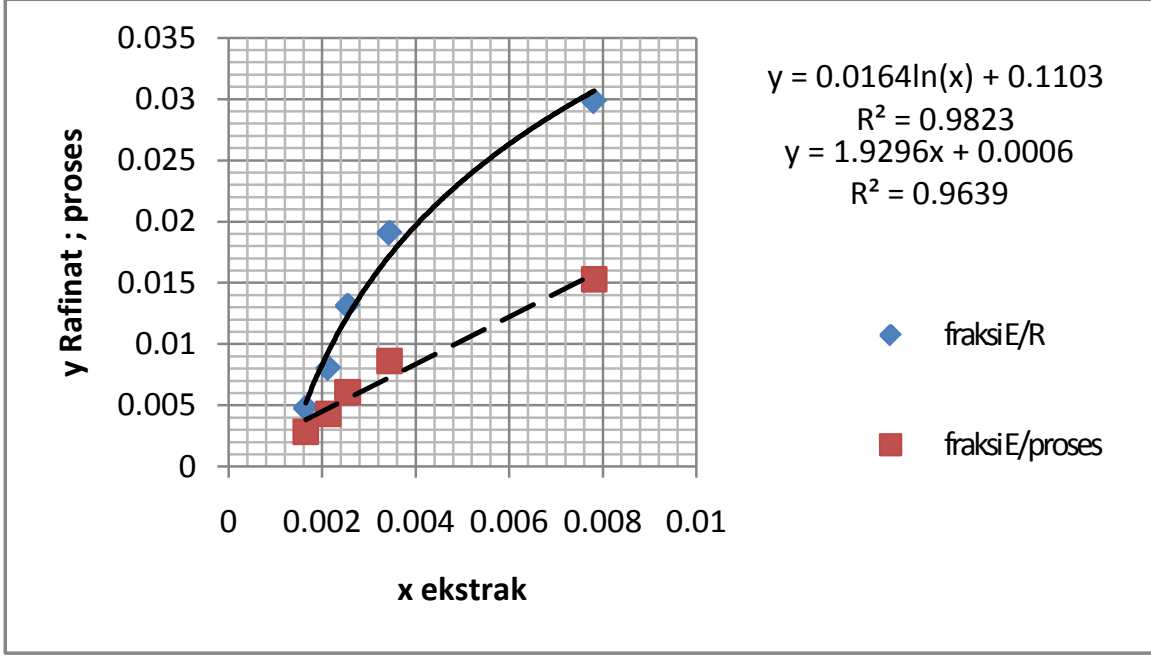

Grafik 1. Hubungan antar fraksi berat pada ekstraksi abu kayu 200 gram.

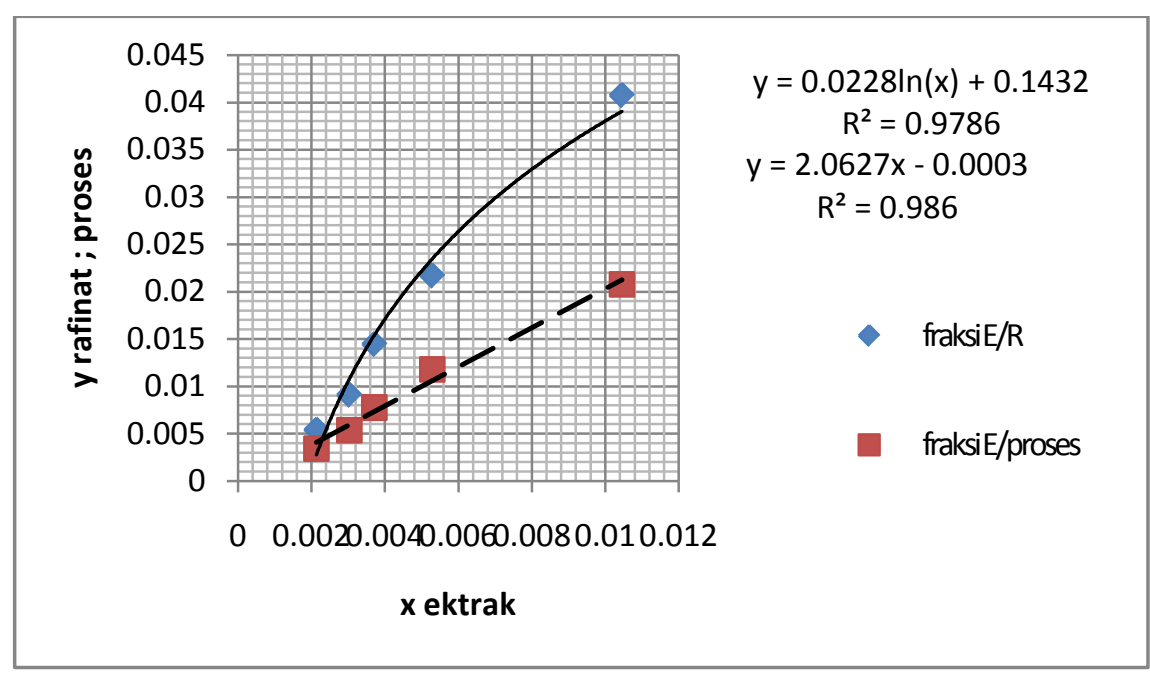

Grafik 2. Hubungan antar fraksi berat pada ekstraksi abu kayu 300 gram.

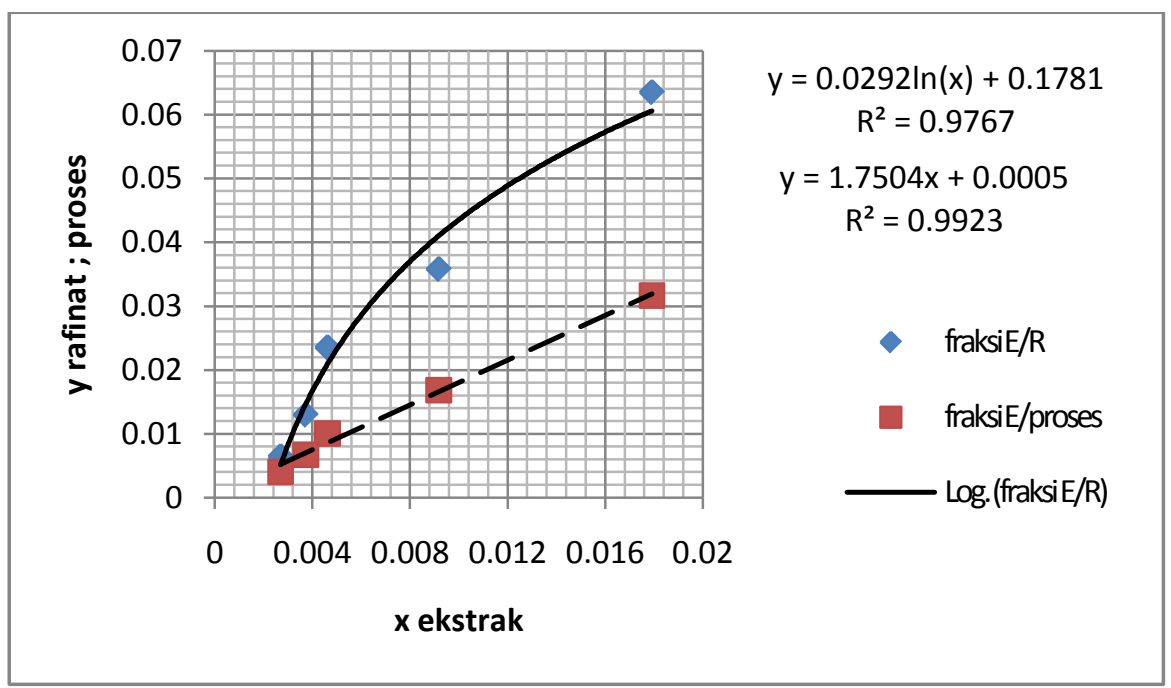

Grafik 3. Hubungan antar fraksi berat pada ekstraksi abu kayu 400 gram. 
Pada ekstraksi abu 300 gramhubungan perbandingan fraksi berat alkali di ekstrak (E) terhadap rafinat (R) cenderung linear tapi karena pada ekstraksi abu 200 dan 400 gram kecenderungan logaritmiknya lebih kuat maka secara umum hubungan perbandingan fraksi berat alkali di ekstrak (E) terhadap rafinat (R) didekati dengan persamaan logaritmik.Garis E/R mirip dengan garis operasi pada ekstraksi kontinyu berlawanan arah.

Dengan melihat nilai $\mathrm{R}^{2}$ di tiap grafik untuk E/R khusunya di ekstraksi abu 200 dan 400 gram yang mencapai 0,98 maka ekstraksi abu selama 5 menit telah mencapai kesetimbangan. Hal ini masuk akal karena larutan yang diekstrak berupa garam dengan asam lemah. Perbandingan antara fraksi berat alkali ekstrak terhadap fraksi alkali berat di proses adalah linear memperkuat dugaan bahwa ekstraksi telah mencapai kesetimbangan. Garis yang menghubungkan berat alkali ekstrak terhadap fraksi alkali berat di proses adalah kurva kesetimbangan.

Dengan menganggap tiap prosesekstraksi adalah sistem bertahap tunggal maka dibuat grafik rangkaian proses ekstraksi yang nampak di grafik 5, 6 dan 7.

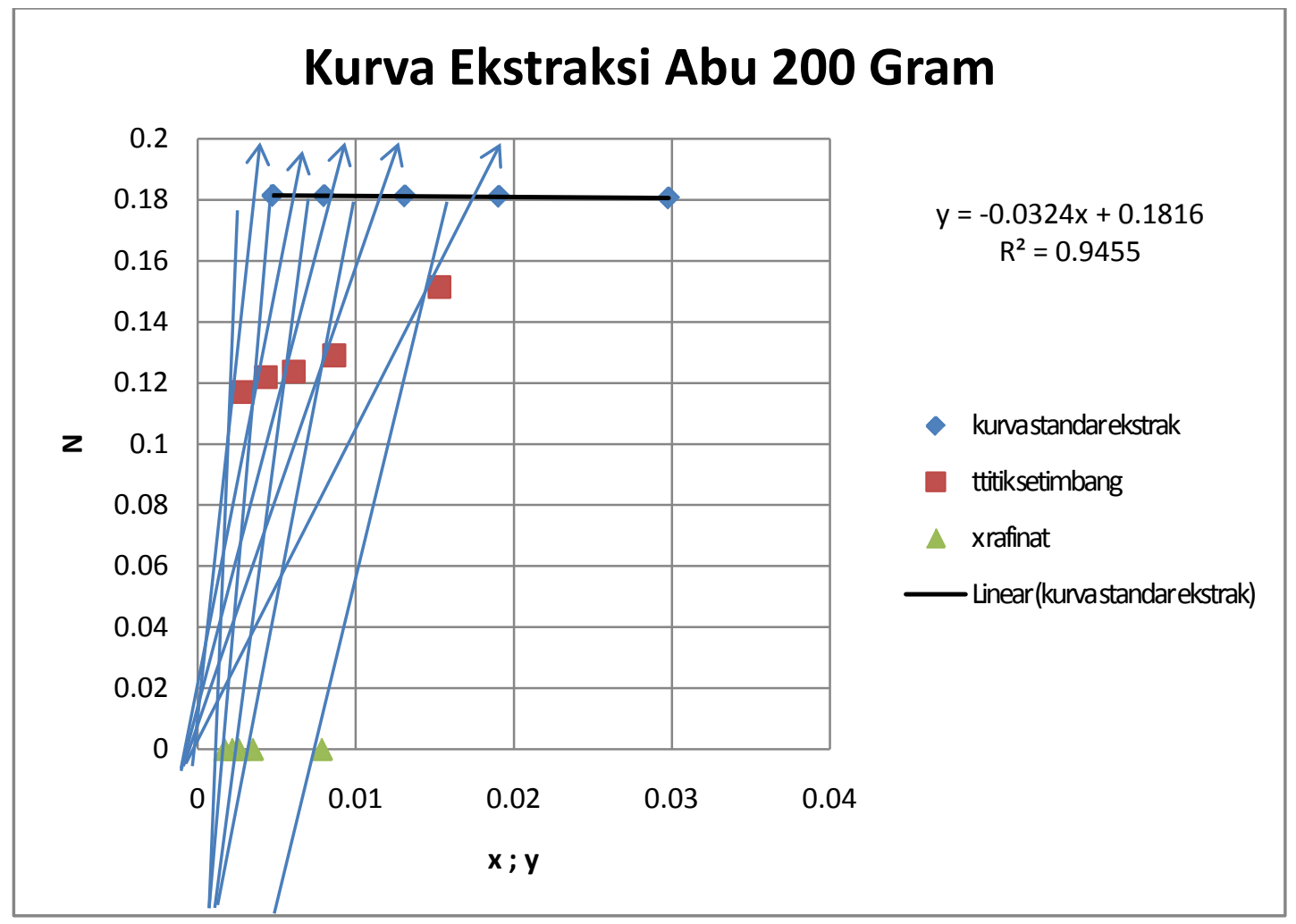

Gambar 4. Grafik rangkain 5 ekstraksi untuk sistem bertahap tunggal dengan umpan segar berupa abu kayu 200 gram. 


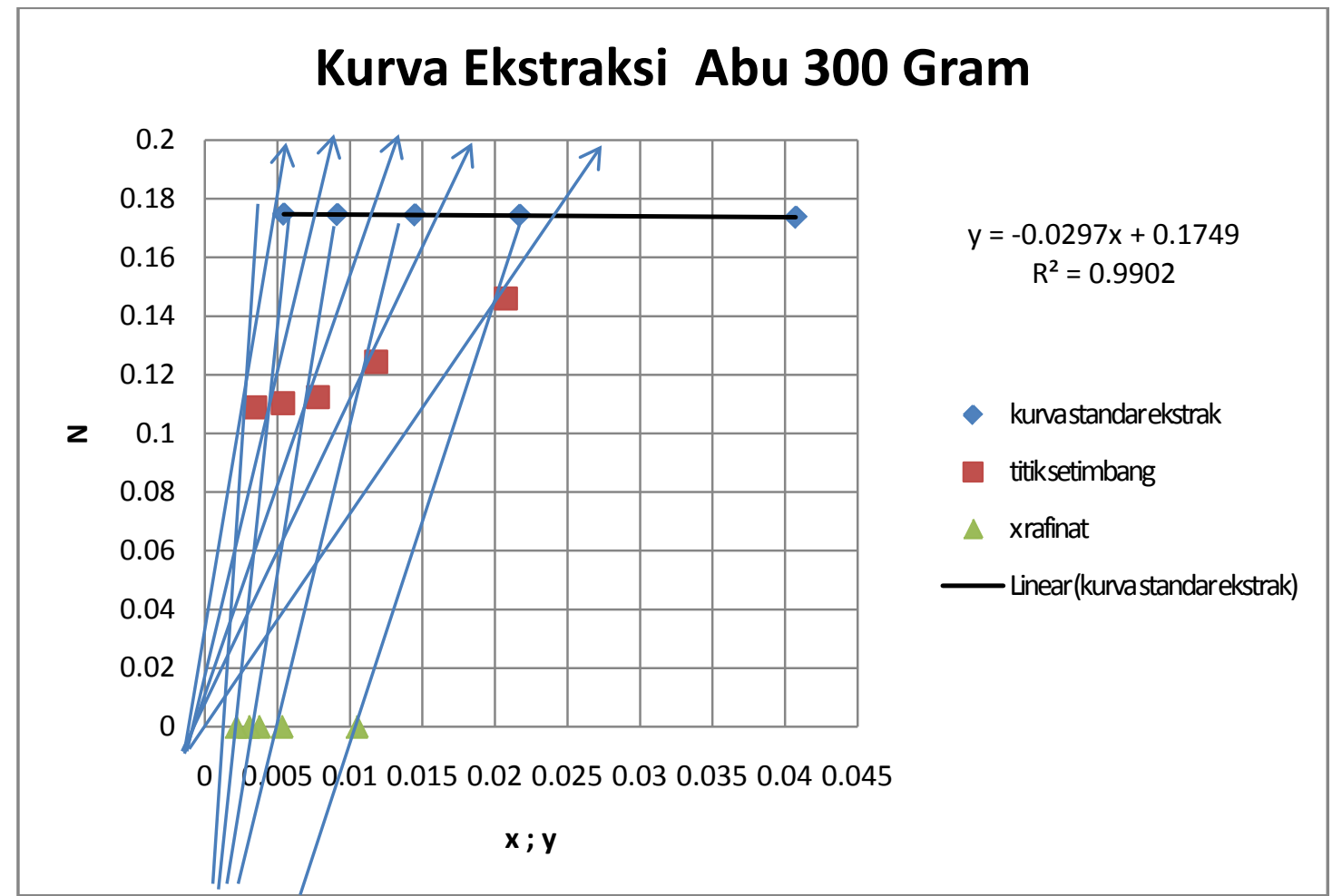

Gambar 5. Grafik rangkain 5 ekstraksi untuk sistem bertahap tunggal dengan umpan segar berupa abu kayu 300 gram.

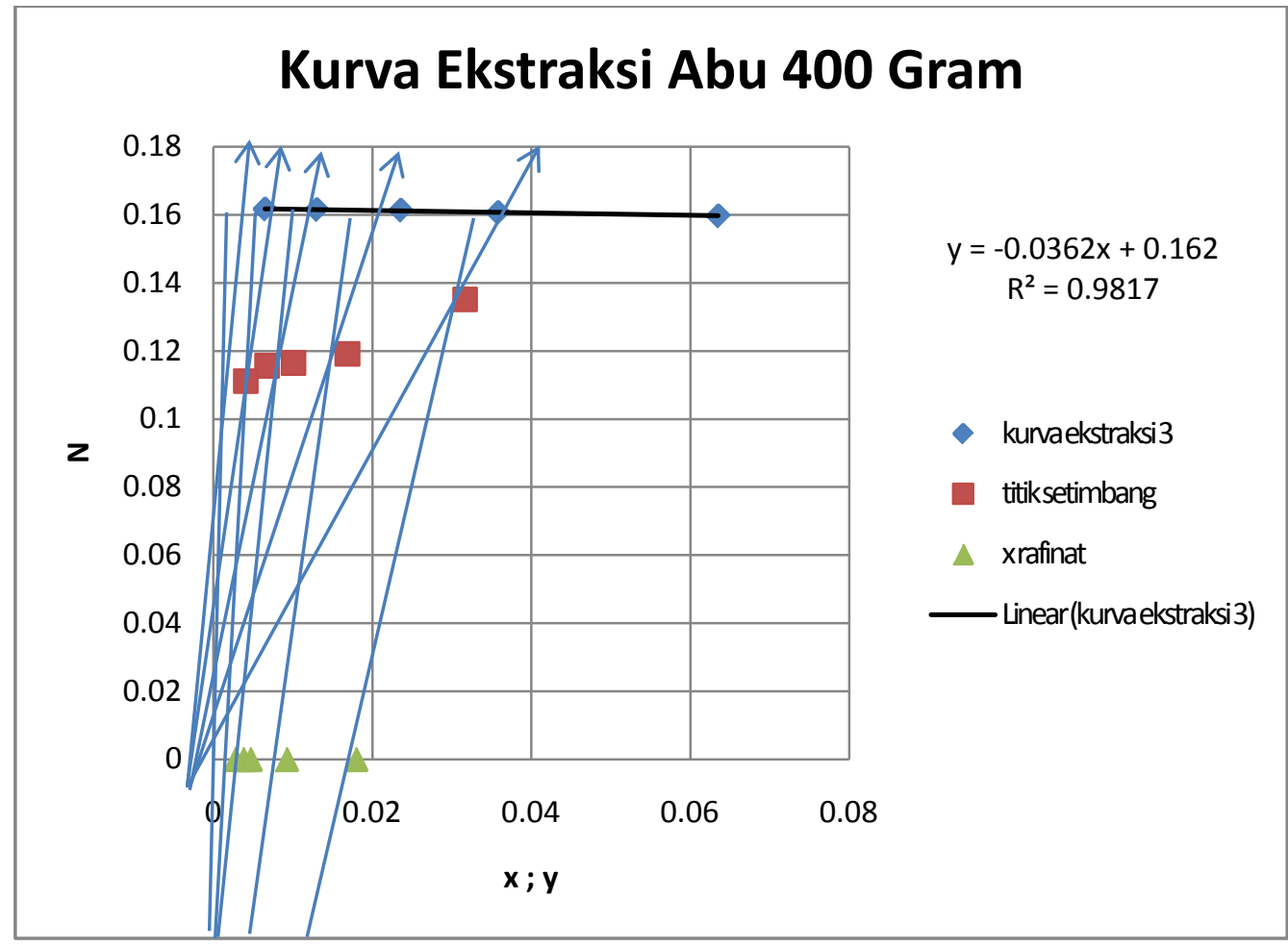

Gambar 6. Grafik rangkain 5 ekstraksi untuk sistem bertahap tunggal dengan umpan segar berupa abu kayu 400 gram. 
Cara menggambar grafik ini, pertama dibuat titik yi terhadap Ni, kemudian antar titik dibuat garis operasional dengan judul kurva ekstraksi. Kedua digambar titik YMi terhadap Nmi yang disebut sebagai titik setimbang, ini adalah kondisi saat proses ekstraksi. Ketiga dibuat titik Ri terhadap xi yang dinamai x rafinat. Keempat ditarik garis Ro dari titik $(0,0)$ dan garis Riyang berpotongan di titik setimbang tiap proses. Perpanjangan garis Ri ke bawah diperkirakan akan menuju satu titik $\Delta \mathrm{R}$ sama dengan deskripsi grafik dari proses ekstraksi leaching berlawanan arah bertahap banyak. Dengan memperpanjang garis Ro sampai ke NFi tiap garis dapat dibaca nilai xFi tiap umpan. Namun nilai NF berkisar 4 sampai 41 maka tidak bisa ditunjukkan pada grafik ini. Perpotongan garis Ri terhadap kurva ekstraksi menghasilkan titik (yi, Ei) nyata, namun hasil perhitungan menunjukkan yi lebih kecil dari nilai yi hitungan neraca masa.Hal ini dimungkinkan karena pemisahan ekstrak dari padatan yang kurang sempurna.

\section{Kesimpulan}

Pada ekstraksi abu kayu dengan pelarut air menggunakan sistem bertahap banyak beraliran silang, dapat dibuat garis operasi yang berupa persamaan logaritmik dan kurva kesetimbangan yang berupa persamaan linear. Selain itu dapat dibuat grafik yang menggambarkan rangkaian 5 tahap operasi yang merupakan gabungan ektraksi bertahap tunggal. Ekstrak abu kayu yang berasal sisa pembakaran untuk pengeringan dari industri pemotongan kayu normalitasnya kecil.

\section{Keterangan Lambang :}

A = berat pelarut murni

$\mathrm{B}=$ berta innert

$\mathrm{C}=$ berat zat terlarut

$\mathrm{E}$ = berat larutan yang berada bersama padatan

$\mathrm{F}$ = berat larutan yang berada bersama padatan umpan

$\mathrm{M}=$ berat total larutan dalam campuran

$\mathrm{N}=\mathrm{B} /(\mathrm{A}+\mathrm{C})$

$\mathrm{R}=$ berat larutan dalam aliran atas

$\mathrm{x}=\mathrm{C} /(\mathrm{A}+\mathrm{C})$ dalam aliran atas

$\mathrm{y}=\mathrm{C} /(\mathrm{A}+\mathrm{C})$ dalam aliran bawah

\section{Daftar Pustaka}

1. Purwono, S, Murachman, B., Yulianti, D.T., dan Suwati., 2005, Koefisien Perpindahan Massa pada Ekstraksi Aspal Buton dari Kabungka dan Bau-Bau dengan Pelarut n-Heksane, Forum Teknik Vol. 29, No. 1

2. Dumanaw, J.F. 1990. Mengenal Kayu. Kanisius. Semarang.

3. Sjostrom, E. 1995. Kimia Kayu, Edisi Kedua. Gadjah Mada University Press. Yogyakarta.

4. Imaduddin, M., Yoeswono, Wijaya, K., Tahir, I., 2008, Ekstraksi Kalium dari Abu Tandan Kosong Sawit sebagai Katalis pada Reaksi Transesterifikasi Minyak Sawit, Bulletin of Chemical Reaction Engineering \& Catalysis, 3(1-3), 14-20

5. Sugiharto, F.X., 1987, Hidrolisis Daun Nenas dengan Ekstrak Abu Menjadi Serat, Laporan Penelitian Proses Kimia, Fakultas Teknik, Universitas Gadjah Mada, Yogyakarta.

6. Sulistiawati, E., 1993, Hidrolisis Sabut Kelapa Menjadi Serat Dengan Katalisator Larutan Ektrak Abu Pada Tekanan di Atas Satu Atmosfer, Laporan Penelitian, Jurusan Teknik Kimia, Universitas Gadjah Mada, Yogyakarta.

7. Pitman, R, 2001, : “ Wood Ash Use in Forestry A Review of The Environmental Impact “, Skog Forsk Report, Swedia.

8. Sulistiawati, E., 2001, Pemanfaatan Limbah Pertanian: Pengambilan Serat dari Sabut Kelapa dengan Ekstrak Abu Kelopak Batang Pisang secara Hidrolisis, Prosiding Seminar Pengelolaan dan Pengolahan Sampah, Universitas Ahmad Dahlan, Yogyakarta. 